\title{
Early prediction of pregnancy induced hypertension by colour Doppler and role of antioxidants
}

\author{
Priya Singh*, Bandana Sharma, Neetu Singh
}

Department of Obstetrics and Gynaecology, GSVM Medical College, Kanpur, Uttar Pradesh, India

Received: 07 June 2016

Accepted: 01 July 2016

\section{*Correspondence:}

Dr. Priya Singh,

E-mail: priyakg05@gmail.com

Copyright: (c) the author(s), publisher and licensee Medip Academy. This is an open-access article distributed under the terms of the Creative Commons Attribution Non-Commercial License, which permits unrestricted non-commercial use, distribution, and reproduction in any medium, provided the original work is properly cited.

\begin{abstract}
Background: Hypertension is one of the commonest medical complications during pregnancy and a leading cause of maternal and perinatal mortality. The objective of this study was to evaluate the efficacy of color Doppler in predicting pregnancy induced hypertension at early gestation by assessing blood flow velocity profile and to assess the role of antioxidants in reducing the oxidative stress of the disease by their effect on pregnancy outcome.

Methods: The study was carried as a blind prospective study in 310 antenatal patients attending the outpatient department and indoor cases of upper India sugar exchange maternity hospital, GSVM Medical College, Kanpur, Uttar Pradesh, India for a period of 18 months.

Results: Early trimester colour Doppler ultrasonography has an excellent role to play as a predictor of pregnancy induced hypertension. However the role of antioxidant supplementation in early pregnancy for amelioration of the process could not be justified.

Conclusions: From the above study it is concluded that early trimester colour Doppler ultrasonography has an excellent role to play as a predictor of pregnancy induced hypertension.
\end{abstract}

Keywords: Pregnancy induced hypertension, Colour Doppler ultrasonography, Antioxidants

\section{INTRODUCTION}

Hypertension is one of the commonest medical complications during pregnancy and a leading cause of maternal and perinatal mortality. Hypertensive disorders complicate 5 to $10 \%$ of all pregnancies and form one member of the deadly triad of maternal mortality contributing to $16 \%$ of maternal mortality in developed countries. The working group of the national high blood pressure education programme (2000) classification of hypertensive disorder complicating pregnancy describes 4 types of hypertensive disease.

- Gestational hypertension

- Pre-eclampsia and eclampsia syndrome
- Pre-eclampsia syndrome super imposed on chronic hypertension

- Chronic hypertension.

Underlying cause of pathophysiologic mechanisms that are thought to be responsible for disease process appears to occur much earlier in pregnancy between 8-18 weeks. For this reason it seems logical to search for earlier indicators of this disease, so that timely diagnosis and intervention may prevent complications and improve pregnancy outcome. ${ }^{1}$ Doppler velocimetry has been most extensively studied technology to assess fetal well-being and predict adverse pregnancy outcome. It is a noninvasive technique which can easily be used as for evaluations of maternal and fetal hemodynamics. ${ }^{2}$ Flow in numerous maternal and fetal vessels have been studied 
to better understand antenatal pathophysiology. Quantitative doppler indices include velocity and flow measurements. Qualitative indices include S/D ratio, resistance index, pulsatility index.

\section{METHODS}

The study was carried as a blind prospective study in 310 antenatal patients attending the outpatient department and indoor cases of upper India sugar exchange maternity hospital, GSVM Medical College, Kanpur, Uttar Praedsh, India for a period of 18 months.

\section{Inclusion criteria}

- Antenatal patients in first and second trimester

- Primi as well as multipara

- With singleton pregnancies (present).

Gestational age of the patient was calculated from the first day of the last menstrual period and if it was not known then by available ultrasonographic parameters preferably in first trimester by crown rump length and in second trimester by bi-parietal diameter and femoral length etc.

\section{RESULTS}

Total 310 patients were enrolled in our study. Out of these 42 patients develop pregnancy induced hypertension $(13.55 \%)$ and 268 patients $(86.45 \%)$ remained normotensive.

Table 1: Total number of cases of PIH and normotensive.

\begin{tabular}{|lll|}
\hline Total no of cases $=310$ & No & $\%$ \\
\hline $\begin{array}{l}\text { Number of cases who } \\
\text { developed PIH }\end{array}$ & 42 & $13.55 \%$ \\
\hline $\begin{array}{l}\text { Number of cases who } \\
\text { remained normotensive }\end{array}$ & 268 & $86.45 \%$ \\
\hline
\end{tabular}

Table 2: Distribution of cases according to abnormal S/D ratio in umbilical artery.

\begin{tabular}{|lll|}
\hline $\begin{array}{l}\text { S/D ratio in } \\
\text { umbilical } \\
\text { artery }\end{array}$ & PIH $(\mathbf{n = 4 2 )}$ & $\begin{array}{l}\text { Normotensive } \\
(\mathbf{n = 2 6 8 )})\end{array}$ \\
\hline$>5.88$ & $28(66.67 \%)$ & $19(7.09 \%)$ \\
\hline$<5.88$ & $14(33.37 \%)$ & $249(92.91 \%)$ \\
\hline & $\begin{array}{l}\text { Sensitivity }= \\
66.67 \%\end{array}$ & $\begin{array}{l}\text { Specificity }= \\
92.91 \%\end{array}$ \\
\hline & PPV $=59.57 \%$ & NPV $=94.67 \%$ \\
\hline
\end{tabular}

Table 2 shows relation of abnormal S/D ratio in umbilical artery and development of PIH. Patients who had elevated S/D ratio in umbilical artery develop preeclampsia subsequently on follow up ( $p$ value $<0.0001)$. Relation of persistent uterine artery notch with development of PIH shown in Table 3. In our study sensitivity of uterine artery notch is $80.95 \%$ and specificity is $93.28 \%$. PPV is $65.38 \%$ and NPV is $96.8 \%$. Table 4 shows relation of uterine artery pulsatility index with development of PIH. At a cut off of $>1.48$ sensitivity is $83.33 \%$ and specificity is $95.15 \%$ in our study. PPV of Ut A PI is $92 \%$ and NPV is $97.33 \%$. Role of antioxidants in PIH shown in Table 5. Incidence of PIH in the antioxidant group is $64.29 \%$ and in control group is $62.96 \%$ implying there is no benefit of antioxidant supplementation for prevention of PIH ( $p$ value $=0.9188$ ).

Table 3: Distribution of cases according to persistent uterine artery notch.

\begin{tabular}{|lll|}
\hline $\begin{array}{l}\text { Uterine } \\
\text { A notch }\end{array}$ & $\begin{array}{l}\text { PIH } \\
(\mathbf{n = 4 2})\end{array}$ & $\begin{array}{l}\text { Normotensive } \\
(\mathbf{n}=\mathbf{2 6 8})\end{array}$ \\
\hline Bilateral & 9 & - \\
\hline Unilateral & 25 & 18 \\
\hline Absent & 8 & 250 \\
\hline & Sensitivity $=80.95 \%$ & Specificity $=93.28 \%$ \\
\hline & PPV $=65.38 \%$ & NPV $=96.8 \%$ \\
\hline
\end{tabular}

Table 4: Distribution of cases according to abnormal uterine artery pulsatility index.

\begin{tabular}{|lll|}
\hline $\begin{array}{l}\text { Pulsatility } \\
\text { index }\end{array}$ & PIH $(\mathbf{n = 4 2 )}$ & $\begin{array}{l}\text { Normotensive } \\
(\mathrm{n}=268)\end{array}$ \\
\hline $\mathrm{PI}>1.48$ & $35(83.33 \%)$ & $13(4.85 \%)$ \\
\hline $\mathrm{PI}<1.48$ & $07(16.67 \%)$ & $255(95.15 \%)$ \\
\hline & Sensitivity $=83.33 \%$ & Specificity $=95.15 \%$ \\
\hline & PPV $=72.92 \%$ & NPV $=97.33 \%$ \\
\hline
\end{tabular}

Table 5: Distribution of PIH patients among patients supplemented with antioxidants (vit-C-1000 mg and vit-E-400IU) and patients who were not supplemented.

\begin{tabular}{|c|c|c|c|}
\hline $\begin{array}{l}\text { Number of patient } \\
\text { with Doppler } \\
\text { abnormalities } \\
(\mathrm{n}=55)\end{array}$ & No. & PIH & Normotensive \\
\hline $\begin{array}{l}\text { Antioxidant } \\
\text { supplementation } \\
\text { given (study group) }\end{array}$ & 28 & $18(64.29 \%)$ & $10(35.71 \%)$ \\
\hline $\begin{array}{l}\text { Antioxidant } \\
\text { supplementation not } \\
\text { given (control group) }\end{array}$ & 27 & $17(62.96 \%)$ & $10(37.04 \%)$ \\
\hline
\end{tabular}

\section{DISCUSSION}

Pregnancy induced hypertension complicates around 5$10 \%$ of all pregnancies and is an important cause of maternal and perinatal mortality and morbidity. Although multiple theories have been proposed for its pathogenesis, abnormal trophoblastic invasion and placental free radical oxidative stress appear to play a major role as causative agents. Several evidences such as definite treatment of pre eclampsia by delivery of placenta and occurrence of 
pre eclampsia in absence of viable fetus confirm the hypothesis. In spite of reduction in morbidity and mortality of pre eclampsia by improvement in maternal and obstetric care, no significant changes occurred in prediction of pre eclampsia and hence it's timely prevention.

In our study, we found that patients who had elevated $\mathrm{S} / \mathrm{D}$ ratio in umbilical artery developed pre-eclampsia subsequently on follow up. Our study in accordance with studies done by Fleisher et al and Bhatt et al. ${ }^{3,4}$ Uterine artery notch seems to be a good predictor of pregnancy induced hypertension. ${ }^{5}$ In our study $\mathrm{p}$ value is $<0.0001$ implying a statistically highly significant association between uterine artery notch and PIH. Uterine artery pulsatility index is a very good discriminator to differentiate between pre-eclampsia and normotensive cases. This finding is supported by studies by Gomez et al and Jurkovic and Juaniaux et al, Cnossens JS et al also found in their study that Pulsatility index, alone or combined with notching, is the most predictive doppler index..$^{6-8}$ Future researches should concentrate on combining uterine artery doppler ultrasonography with other tests.

\section{CONCLUSION}

From the above study it is concluded that early trimester colour doppler ultrasonography has an excellent role to play as a predictor of pregnancy induced hypertension. However the role of antioxidant supplementation in early pregnancy for amelioration of the process could not be justified. It is suggested that further trials with large sample sizes be carried out to further evaluate the role of various screening strategies in prediction of PIH and also the role of antioxidant supplementation.
Funding: No funding sources Conflict of interest: None declared

Ethical approval: The study was approved by the Institutional Ethics Committee

\section{REFERENCES}

1. Berg CJ, Harper MA, Arkinson SM, Bell EA, Brown HL, Hage ML, et al. Preventibility of pregnancy related deaths. Obstet Gynecol. 2005;106(6):122834.

2. Fitzgerald DE, Drumm JE. Non-invasive measurement of human fetal circulation using ultrasound: a new method. $\mathrm{Br}$ Med J. 1977;2(6100):1450-1.

3. Fleischer A, Schulman H, Farmakides G, Braccro L. Uterine artery Doppler velocimetry in pregnant women with hypertension. Am J Obstet Gynecol. 1986;154:806-13.

4. Bhatt CJ, Arora J, Shah MS. Role of color Doppler in pregnancy induced hypertension. Indian J Radiol imaging. 2003;13:417-20.

5. Schulman H, Fleischer A. Significance of absent end diastolic velocity in umbilical artery waveforms Am J obstet Gynecology. 1987;156:1213:8.

6. Gomez O, Figueras F, Martinez JM, del Rio M, Palacio M, Eixarch E, et al. Sequential changes in uterine artery blood flow pattern between the first and second trimesters of gestation in relation to pregnancy outcome. Ultrasound Obstet Gynecol. 2006;28(6):802-8.

7. Jaunizux E, Jurkovic D, Campell S. Doppler ultrasonographic features of the developing placental circulation with abatomic findings. Am J Obstet Gynecol. 1992;166:585-7.

8. Cnossens JS, Morris RK, Ter Riet G, Mol BW, Vander JA, Coomaraswamy A, et al. Use of uterine a doppler ultrasonography to predict pre-eclapsia and intrauterine growth restriction a systematic review and bivariable meta-analysis. CMAJ. 2008;178(6): 701-11.

Cite this article as: Singh $\mathrm{P}$, Sharma $\mathrm{B}$, Singh N. Early prediction of pregnancy induced hypertension by colour Doppler and role of antioxidants. Int J Reprod Contracept Obstet Gynecol 2016;5:2677-9. 